\title{
An evaluation of application of information technology and communication of learning science with the theme of solar system
}

\author{
Septiana Indri Hapsari ${ }^{1}{ }^{*}$, Kristian Handoyo Sugiyarto ${ }^{1}$, Naoko Kosaka ${ }^{2}$ \\ ${ }^{1}$ Universitas Negeri Yogyakarta. Jalan Colombo No. 1, Karangmalang, Yogyakarta, 55281, Indonesia \\ ${ }^{2}$ Graduate School of Science and Technology, Shizuoka University \\ * Corresponding Author. Email: hapsari.indri781@gmail.com
}

Received: 6 September 2018; Revision: 17 September 2018; Accepted: 20 September 2018

\begin{abstract}
The study aims at identifying: (1) the teachers' preparedness in implementing the ICT into the Natural History learning process; (2) the compatibility level of the ICT implementation in the conduct of Natural History learning process; and (3) the level of students' passing grade after the ICT implementation into the Natural History learning process. Then, in conducting the evaluative study the researcher employed the Countenance Stake Model that consisted of Antecedent, Transaction and Outcomes. The respondents who had been involved in the study were the teachers of Natural History for Grade VII students in Negeri 5 State Junior High School, Negeri 8 State Junior High School, Negeri 15 State Junior High School and Pangudi Luhur 1 Junior High School. The data were gathered by means of purposive sampling through the use of the following instruments: observation sheet, teacher questionnaire, student questionnaire, interview guideline and document checklist for lesson plans. On the contrary, the data analysis technique that had been employed were the quantitative approach in the form of $t$-score and the qualitative approach in the form of description. The results of the study show that: (1) the teachers' preparation in implementing the ICT has not been maximum; (2) the compatibility level on the ICT implementation into the Natural History learning process is already good as having been shown by the following mean score: $48.74 \%$ in the opening activities, $53.21 \%$ in the main activities and $47.20 \%$ in the closing activities and also $36.74 \%$ on the assessment activities with the range from $56.00 \%-68.00 \%$; and (3) the results of the students' learning process have not been satisfying yet namely $62.72 \%$ from the normal standard $70.00 \%$.
\end{abstract}

Keyword: evaluation, ICT implementation, natural history learning process

\section{INTRODUCTION}

The global problem of education domain that the Republic of Indonesia should be dealing with is preparing the young generation to compete and survive in the digital era both in the present time and in the future. As a result, the government is demanded to equip the young generation of Indonesia with an education that exercises the skills of the $21^{\text {st }}$ century. Sutrisno $(2011$, p.8) explains that the skills of the $21^{\text {st }}$ century include higher order/critical thinking, solution finding, creativity, innovation, communication, collaboration and information and communication technology (ICT) literacy. In relation to the ICT literacy, the Pacific Policy Research Centre (2010, p.2) defines that the ICT literacy includes the skills of gathering, combining, processing, delivering and evaluation the quality and compatibility of information from multiple sources.

ICT is a set of tools that might serve as a transmitter, a processor and a deliverer of the information that has been retrieved from one device to another (Rusman, 2010, p.75). Furthermore, Toomey (2001, p.3) explains that ICT consists of hardware and software. Hardware consists of physical ICT equipment such as television, computer, printer, LCD and alike. On the other hand, software consists of non-physical ICT equipment such as application and Internet.

The implementation of ICT is important to pursue in the education domain. The reason is that ICT brings about huge influence on both the teachers and the students since ICT provides an opportunity for both of them to adapt the teaching-learning activities into the individual needs of the students as a response toward the innovative technology. In addition, ICT also brings about huge 
impact on the learning approach within the classroom. In other words, ICT might contribute to changing the school service, the school innovation and the practice of the learning activities.

Learning is a highly important aspect within the education. Learning takes more than a sequence of knowledge transfer from the teachers to the students because in the learning process nowadays the teacher is demanded to perform a constructivist learning in which the students actively seek and construct their own knowledge while the teachers serve more as a facilitator. The learning process in the school is performed in accordance to the principles of the curriculum that has been governed. With regards to the statement, the Republic of Indonesia has undergone 11 changes of curriculum since 1945. Until the academic year 2015/2016, most of the schools in Indonesia have been implementing the 2013 Curriculum while the remaining schools have been implementing the Educational Unit Level Curriculum.

The 2013 Curriculum has been considered a compatible curriculum for replacing the Educational Unit Level Curriculum. Within the 2013 Curriculum, there are many changes on both the mind sets and the principles within the learning process. The Ministry of Education and Culture (Kementerian Pendidikan dan Kebudayaan Republik Indonesia, 2013) explains that one of the learning principles that have been formulated in the 2013 Curriculum is using the scientific method that involves the activities of observing, gathering, processing, analysing and communicating. In addition, the learning process in the 2013 Curriculum is performed by using multiple sources and one of these sources is the ICT. With regards to the implementation the 2013 Curriculum, the government has issued the Ministerial Regulation Number 103 Year 2014, as the revision of the Ministerial Regulation Number 65 Year 2013, which contains the Standards of Process in the Elementary and High Education Degree. Verse 13 of the Ministerial Regulation Number 103 Year 2014 states that the use of information and communication technology should be pursued in order to improve the effectiveness and the efficiency of the learning process. Thereby, the implementation of ICT in the learning activities might refer to the standards of process that have been outlined in the Ministerial Regulation Number 103 Year 2014 as the implementation criteria.

The implementation of ICT is very useful in the learning process. Voogt (2009) in his study has found that the use of ICT by the teachers of Natural History might change the students' achievement. Then, the use of the ICT in his study includes the knowledge on the learning materials, the skills of ICT operation, the learning motivation, the independent learning skills, the communication skills, the information processing, the collaboration skills, the direct independent learning, the problem-solving, the achievement and the self-appreciation.

Furthermore, the implementation of ICT might change the teachers' way of teaching. The changes might include the teachers' quality in guiding the students, the time management for assisting the students in the learning process, the problem-solving activities, the preparation, the class management, the class discussion, the collaboration with the students, the communication with the external world, the capacity of delivering the new learning materials by facilitating the students' needs, the motivation toward the students, the record of the students' development and the improvement of self-confidence.

The implementation of ICT might be pursued in all subjects, including Natural History. Natural History is one of the branches in science that studies matters, body and phenomena that take place around the universe. Carin \& Sund (1989, p.5), Wonorahardjo (2009, p.12), Trefil \& Hazen (2010, p.20) similarly define that Natural History is a set of knowledge and learning methods about the universe by using a scientific method that employs careful inquiry, observation, measurement and experiment. Chiapetta \& Koballa (2010, p.256) mention that there are three significances that Natural History has namely a way of thinking, a way of investigating and body of knowledge through the position of being product, process and attitude.

Nowadays learning the Natural History does not only deal with memorizing and calculating activities but also investigating and reviewing natural phenomena through a holistic and integrative manner in order that the students will be able to solve the problems not only from one point of view but also from several points of view that have been collaborated in order to find wiser solution. The same principle also applies in learning about the universe. The theme of Universe in Natural History discusses many sky objects including the earth in which people have been living along with the other phenomena that might impact the living organism. 
Similarly, knowledge about galaxy has been developing and thus the teachers are demanded to always update and upgrade their knowledge. Therefore, in delivering the materials around galaxy the teachers might rely on the use of more varied method and sources. If the use of textbooks or props have been insufficient, the teachers might have started to consider the use of ICT technology such as video, games and alike. The use of ICT technology has been supported by the results of a study by Tantriadi (2013) which show that the use of ICT technology such as interactive encyclopedia has been able to decrease the students' boredom, to improve the students' motivation, to elicit the students' understanding and to assist the teachers within the learning process of Natural History under the theme "Galaxy."

The implementation of ICT into the learning materials of the theme "Galaxy." has been pursued in several regions and one of these regions is the City of Yogyakarta. The City of Yogyakarta, as the City of Education, has been noted to display the highest figure of computer and Internet use in comparison to the four regions within the Province of Yogyakarta Special Region. Based on the data that have been retrieved from the Central Bureau of Statistics Ministry of Communication and Information Province of Yogyakarta Special Region, it has been identified that from 2012 until 2014 the use of Internet for learning purpose in the Province is $49.13 \%$ with the following composition: $94.73 \%$ of the Internet has been accessed by the university students while $81.39 \%$ of the Internet has been accessed by the junior high school students. However, the significant portion on the use of Internet by the junior high school students should be monitored by both the teachers and the parents.

Furthermore, based on the results of the pre-survey activities it has been found as well the junior high schools within the City of Yogyakarta have been installing LCDs and projectors in each classroom and the Natural History laboratory since 2013/2013 Academic Year. In addition, these junior high schools have also opened computer laboratory with sufficient number of computer units for the students. In the same time, these facilities might be benefitted for the learning process of Natural History. Unfortunately, in the practice there have been many teachers who have rarely implemented or who have not even implemented the ICT into the learning process of the Natural History subject. This information has been retrieved from the students in one of the junior high schools during the pre-survey activities; according to the students, one of the Natural History teachers have only implemented the ICT into the Natural History once in a year. Similarly, in other junior high schools within the same region there are still many teachers who have considered that the use of ICT will cause the implementation of scientific approach to be less maximum. Not only that, it has also been retrieved that one of the junior high schools that have implemented the 2013 Curriculum has not evaluated the ICT implementation especially in the Natural History learning process. The only evaluation that used to conduct is the monitoring activities by the supervisor in certain period of time.

The learning process of Natural History in the 2013 Curriculum is ideally performed by implementing the ICT. ICT might be benefitted for facilitating the activities within the framework of scientific approach. In addition, in each learning activities that makes use of ICT implementation there should be an evaluation in order to identify the quality and to take decisions in relation to the sustainability of the activities that have been performed, specifically whether the implementation ICT in the learning process of Natural History under the theme "Galaxy" should be sustained, be modified or be terminated. The evaluation itself might also serve as a matter of consideration for defining the appropriate solutions for improvement. Looking at the situation, the researcher deems necessary to conduct a study under the following title: "The Evaluation on the Implementation of ICT within the Learning Process of Natural History toward the Junior High Schools in the City of Yogyakarta."

\section{METHOD}

The study was a program evaluation using the Countenance Stake model. The Countenance Stake model that had been implemented in the study consisted of description and judgment toward the evaluation object. Then, the study took place from November 2015 until June 2016 in 4 junior high schools that implemented the 2013 Curriculum in the Academic Year 2015/2016. The 4 junior high schools that had been selected were Negeri 5 Yogyakarta State Junior High School, Negeri 8 Yogyakarta State Junior High School, Negeri 15 Yogyakarta State Junior High School Yogyakarta and Pangudi Luhur Junior High School.

Then, the population within the study was the teachers of Natural History and the students of Grade VIII in the junior high schools that had implemented the 2013 Curriculum in the Academic 
Year 2015/2016 within the City of Yogyakarta. The sample that would be selected to be the respondents in the study was defined by employing the purposive sampling technique. In employing the purposive sampling technique, the researcher operated the Slovin formula that had been quoted from Sarjono \& Julianita (2011, p.30) with significance rate 5\% as follows:

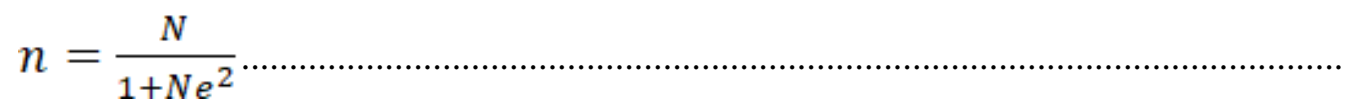

Note:

$\mathrm{n}=$ sample size

$\mathrm{N}=$ number of population

$\mathrm{e}=$ error of tolerance value

The population of junior high school teachers that taught Natural History under the framework of 2013 Curriculum in the Academic Year 2015 / 2016 was 12 people. Based on the Slovin requirements, the number of respondents that had been selected was 8 people. However, due to certain obstacles the teachers that had been selected as the respondents in the study became 5 people. On the contrary, the number of respondents from the students was adjusted to the number of the students that the 5 selected teachers had taught. In brief, there were 5 teachers and 345 students that had become the respondents for the conduct of the study. The detail compositions on these teachers and students were as follows: 2 teachers and 165 students from Negeri 5 Yogyakarta State Junior High School, 1 teacher and 28 students were from Negeri 8 Yogyakarta State Junior High School, 1 teacher and 86 students were from Negeri 15 Yogyakarta State Junior High School and 1 teacher and 66 students were from Pangudi Luhur Junior High School.

The study then proceeded into three stages. The first stage was Antecedent (suggestion/ preparation). The aim of the first stage was to identify the preparedness in the implementation of ICT from the understanding and the experiences of the teachers in relation to the use of ICT and also from the lesson plans of Natural History that the teachers had designed. In brief, the aspects that had been under observation within the first stage were the teachers' understanding and experience in using the ICT and the teachers' lesson plans. Next, the second stage was Transaction (process/execution). The aim of the second stage was to identify the compatibility between the ICT implementation and the learning process on the introductory activities, the core activities, the closing activities and the assessment activities. The aspects that had been under observation within the second stage were the ICT implementation in the introductory activities, the core activities, the closing activities and the assessment activities. The criteria that had been the reference within the observation were related to the ICT collaboration in an effective learning process which might be found in the standard process of Ministerial Regulation Number 103 Year 2014. Each stage of these learning activities had certain criteria. The criteria in the introductory activities were as follows: (1) ICT facilitates the classroom conditioning efforts; (2) ICT facilitates competence presentation; (3) ICT facilitates learning guidelines distribution; and (4) ICT facilitates the assessment activities introduction. Then, the criteria in the core activities were as follows: (1) ICT facilitates the problem presentation; (2) ICT facilitates the observation by the supporters; (3) ICT facilitates inquiry by the observers; (3) ICT facilitates assignment provision; (4) ICT facilitates analysis by the observers; (5) ICT facilitates communication by the observers; (6) ICT facilitates interactivity by the observers; (7) ICT facilitates inspiration for the observers; (7) ICT facilitates motivation for the observers; (8) ICT facilitates creativity from the observers; (9) ICT develops attitudes within the observers. Next, the criteria in the closing activities were as follows: (1) ICT facilitates verification; (2) ICT facilitates feedback from observers; (3) ICT facilitates reflection; and (4) ICT facilitates repetitive learning discussion. Last but not the least, the criteria for the assessment activities were as follows: (1) ICT facilitates the assessment support; (2) ICT facilitates the remedial support; and (3) ICT facilitates the enrichment support. The results of observation on these activities then were analysed in order to identify both the compatibility and the discrepancy between the ICT and the learning process. Eventually, the third stage was Outcomes (output/results). The aim of the third stage was to identify the students' achievement after the implementation of ICT into the learning process of Natural History and also the obstacles that both the teachers and the students had encountered during the implementation of ICT into the learning process of Natural History under the theme "Galaxy." 
In gathering the data during the conduct of the study, the researcher implemented the following technique: (1) questionnaire distribution; (2) observation; (3) interview; and (4) document checklist. The questionnaire distribution was performed by the researcher, who served as the observer and the interview was also performed by the researcher to the teachers in a structured manner with reliance to the interview guidelines. Last but not the least, the document checklist was performed by the researcher in relation to the documentary study on the lesson plans that the teachers of Natural History had designed.

On the contrary, the instruments that had been implemented in the conduct of the study were observation sheet, teacher questionnaire, student questionnaire, interview guidelines, and document checklist sheet. The observation sheet, the teacher questionnaire and the student questionnaire were distributed in order to retrieve the information from the observer, the teachers and the students with regards to the implementation of ICT into the learning process of Natural History, the type of ICT that had been employed in the learning process of Natural History, and also the obstacles and the suggestions in relation to the implementation of ICT into the learning process of Natural History. Then, the interview guidelines were employed in order to retrieve the in-depth data in relation to the teachers' understanding and experience about the implementation of ICT into the learning process of Natural History and the facilities that support the implementation of ICT. Last but not the least, the document checklist was employed in order to retrieve the data on the teachers' preparedness in implementing the ICT into the learning process of Natural History in the form of lesson plans. Through the document checklist, the involvement of ICT in the lesson plans that the teachers had designed might be identified.

The instruments that had been designed should be put into the validity test and the reliability prior to the actual implementation. The validity test was performed in order to identify whether the measurement tool had been really able to provide empirical information in accordance to the objects under measurement (Subali \& Sunyata, 2012, p.40). On the contrary, the reliability test was performed in order to identify the measurement consistency in the repetitive measurement.

The validity test in the study consisted of the content validity test and the empirical validity test. The content validity test involved expert judgment activities and the experts that had been involved were the ones from the following domain: evaluation, learning process of Natural History, technology and practitioners. The results of the content validity test were attained by operating the Aiken $\mathrm{V}$ formula with 2-scale minimum limit of assessment acceptance (dichotomous) by 7 validators defined at 1.00 (Aiken, 1985). On the other hand, the results of the empirical validity test for the dichotomous data were attained by operating the Rasch-Category Model Item Response Theory (IRT) with the calculation from the Quest program. Then, lookin at the description on the results of INFIT MNSQ and INFIT $t$ an item would be considered fit if the INFIT MNSQ would have been between 0.77 and 1.30 and the INFIT $t$ would have been between -2.0 and +2.0 with probability 0.05 (Subali \& Suyata, 2012, p.61).

Next, the reliability of the instruments in the study was shown by the score of the Cronbach's Alpha form the Interclass Correlation Coefficient (ICC) matrix which had been calculated by the IBM SPSS Statistics 20. Then, the criteria of Cronbach's Alpha coefficient might be consulted in Table 1.

Table 1. Cronbach's Alpha Coefficient

\begin{tabular}{cc}
\hline Coefficient Value & Criteria \\
\hline$\alpha \geq 0.90$ & Excellent, \\
$0.90 \geq \alpha \geq 0.80$ & Good, \\
$0.80>\alpha \geq 0.70$ & Acceptable, \\
$0.70>\alpha \geq 0.60$ & Questionable, \\
$0.60>\alpha \geq 0.50$ & Poor, \\
$0.50>\alpha$ & Unacceptable \\
\hline
\end{tabular}

Source: Gliem \& Gliem (2003. P.87)

Furthermore, a Kappa Index calculation was also performed toward the observation sheet in order to identify the inter-rater agreement. The criteria for the inter-rater agreement might be consulted in Table 2. 
Psychology, Evaluation, and Technology in Educational Research, 1 (1), 2018, 46

Septiana Indri Hapsari, Kristian Handoyo Sugiyarto, Naoko Kosaka

Table 2. Inter-Rater Agreement Criteria (Viera \& Garrett, 2005, p.362)

\begin{tabular}{cl}
\hline & \multicolumn{1}{c}{ Kappa Agreement } \\
\hline$<0$ & Less than chance agreement \\
$0.01-0.20$ & Slight agreement \\
$0.21-0.40$ & Fair agreement \\
$0.41-0.60$ & Moderate agreement \\
$0.61-0.80$ & Substantial agreement \\
$0.81-0.99$ & Almost perfect agreement \\
\hline
\end{tabular}

Based on the validity and reliability calculation, the overall results of each instrument might be consulted in Table 3.

Table 3. Results of the Instrument's Validity and Reliability

\begin{tabular}{lcr}
\hline \multicolumn{1}{c}{ Instrument } & V-Aiken Value & Reliability Value \\
\hline Observation Sheet & 1 & 0.850 \\
LO Kappa & 1 & 0.692 \\
Teacher Questionnaire & 1 & 0.850 \\
Student Questionnaire & 1 & 0.970 \\
Interview Guidelines & 1 & - \\
Document Checklist & 1 & - \\
\hline
\end{tabular}

\section{Data Analysis Technique}

The data that have been retrieved from the field are analysed by using the qualitative and the quantitative approach. The qualitative approach is performed toward the observation sheet, teacher questionnaire and student questionnaire. On the contrary, the qualitative approach is performed toward the interview guidelines and the document checklist.

The data that have been retrieved from the respondents, namely the observers, the teachers and the students, are calculated in terms of mean score and deviation standard. Then, departing from the standard deviation the $\mathrm{Z}$ score (the distance of the mean score within the standard deviation) of the data is calculated. In order to eliminate the negative in the $\mathrm{Z}$ score, the $\mathrm{Z}$ score is converted into the $\mathrm{T}$ score by 10-times multiplication. The results of the $\mathrm{T}$ score then are grouped based on the aspects namely introductory activities, core activities, closing activities and assessment activities. Then, the data are triangulated by the observers, the teachers and the students in order to attain the single response so that the decision-making process will be easier. The triangulation is performed by weighing the scores from the observers, the teachers and the students. The results of the weighing activities are known as composites. The composites of each aspect are categorized based on their compatibility by using the category shown in Table 4.

Table 4. The Criteria of ICT Implementation Compatibility in the Learning Process (Mardapi, 2008).

\begin{tabular}{cll}
\hline No. & \multicolumn{1}{c}{ Score Range } & \multicolumn{1}{c}{ Category } \\
\hline 1. & $X i+1.8 S B i<\bar{X}$ & Highly Compatible \\
2. & $X i+0.6 S B i<\bar{X} \leq X i+1.8 S B i$ & Compatible \\
3. & $X i-0.6 S B i<\bar{X} \leq X i+0.6 S B i$ & Moderately Compatible \\
4. & $X i-1.8 S B i<\bar{X} \leq X i-0.6 S B i$ & Incompatible \\
5. & $\bar{X} \leq X i-1.8 S B i$ & Highly Incompatible \\
\hline
\end{tabular}

Based on the compatibility criteria by Mardapi (2008, p.123), the assessment criteria might be consulted in Table 5.

Table 5. The Criteria of ICT Implementation Assessment in the Learning Process of Natural History

\begin{tabular}{ccc}
\hline Score Interval & Nilai & Kategori \\
\hline $\mathrm{X}>68$ & $\mathrm{~A}$ & Very Good \\
$56<\mathrm{X} \leq 68$ & $\mathrm{~B}$ & Good \\
$44<\mathrm{X} \leq 56$ & $\mathrm{C}$ & Moderate \\
$32<\mathrm{X} \leq 44$ & $\mathrm{D}$ & Poor \\
$\mathrm{X} \leq 32$ & $\mathrm{E}$ & Very Poor \\
\hline
\end{tabular}


Psychology, Evaluation, and Technology in Educational Research, 1 (1), 2018, 47

Septiana Indri Hapsari, Kristian Handoyo Sugiyarto, Naoko Kosaka

\section{RESULTS AND DISCUSSIONS}

The first stage, namely Antecedent, is the stage of exposing feedback namely the factors that support the ICT implementation into the learning process of Natural History under the theme "Galaxy." The factors that belong to the Antecedent stage are teachers' understanding toward ICT, teachers' experience with regards to the use of ICT, teachers' frequency in attending the training program of ICT use within learning process, teachers' efforts in designing and updating the ICT for the learning process, the types of ICT that teachers have mostly implemented and teachers' obstacles in implementing the ICT into the learning process.

The Antecedent stage is performed by interviewing the teachers and from the interview with the teachers it is found that the teachers of Natural History in the junior high schools throughout the City of Yogyakarta have not had sufficient understanding and experience toward the use of ICT. One fifth of the sample in the study state that they have been frequently provided by the ICT-related training programs, both the ones held by the Office and the ones held by the Central Government, while the remaining sample stated that they have rarely been provided with the ICT-related training programs for the learning process. The reason for such discrepancy is that the teachers have been appointed by the schools to attend the ICT-related training program as part of equalizing the teachers' training program participation; as a result, not all teachers are able to attend the program. Not to mention, the teachers also have abundant duty to perform and thus they do not have sufficient time to learn the ICT implementation independently and not all teachers of Natural History are interested to implement the ICT into the learning process of Natural History. This situation is in contradiction to the argument by Surjono $(2012$, p.2), who states that one of the requirements for the ICT implementation into the learning process of Natural History is that teachers should have good understanding and experience with regards to the ICT implementation. In addition, according to Ali, Haolader \& Muhammad (2013, p.4069), in order that ICT is successfully implemented into the learning process the teachers should have positive attitude toward the ICT, the teachers should actively attend the training and education programs held by the local Office of Education and the local Forum of Subject Teachers and the teachers should learn to develop their capacity in implementing the ICT into the learning process with their colleagues.

In relation to the previous paragraph, the teachers of the junior high schools throughout the City of Yogyakarta who have been sampled in the study still lack of capacity in implementing the ICT into the learning process. Two of five teachers who have been interviewed state that they have not designed the lesson plans for the learning process of Natural History under the theme "Galaxy" while three of five teachers state that they have designed the intended lesson plan but they have not included the ICT implementation into the learning activities. Ideally, a teacher should design the lesson plan prior to the conduct of the learning activities by involving the ICT as one of the learning sources. The reason is that the lesson plan that has been designed will be used by the teachers as the guidelines in performing the learning activities. In other words, it might be stated that good preparation will result in maximum implementation.

The second stage, namely Transaction, is the stage of exposing the ICT implementation process within the learning process of Natural History under the theme "Galaxy" through the introductory, core, closing and assessment activities. The Transaction stage is performed by distributing questionnaire and performing observation on the ICT implementation within the learning process of Natural History. After the questionnaire distribution and the observation have been done, the results are compared to the criteria that have been assigned as the assessment standards namely the standard of process from the Ministerial Decree Number 103 Year 2014. The results of the data analysis in the introductory activities show the percentage of ICT implementation in facilitating each indicator within the learning activities. These results might be consulted in Figure 1. 
Psychology, Evaluation, and Technology in Educational Research, 1 (1), 2018, 48

Septiana Indri Hapsari, Kristian Handoyo Sugiyarto, Naoko Kosaka

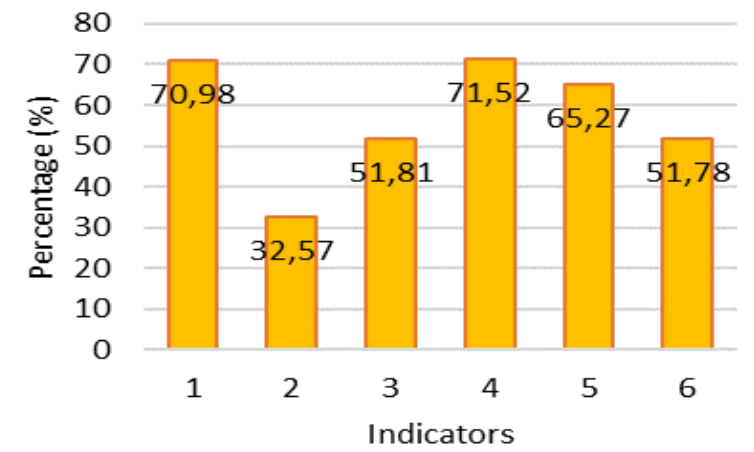

Figure 1. The Histogram of Compatibility for the ICT Implementation in the Introductory Activities

Legends of Indicators:

1 : Conditioning the learning situation

2 : Discussing the previous competence and the present competence that will be developed

3 : Delivering the competence that should be achieved

4 : Delivering the outline of material coverage

5 : Delivering the learning activities that will be performed

6 : Delivering the assessment technique

Departing from the results in Figure 1, it is apparent that the ICT implementation has been very good for the first indicators (conditioning the learning situation) and the fourth indicator (delivering the outline of material coverage). The reason is that the teachers deliver the outline of material coverage and the students' apperception altogether in the same time; as a result, the teachers are able to draw the students' attention. In this regard, the ICT implementation is good for explaining the activities that will be performed, the competence that should be achieved and the assessment technique. Despite the significant achievement in this aspect, the ICT implementation is still very low for explaining the association between the previous materials and the present materials. The cause that lies behind the problem is that the teachers have been accustomed to do the comparison by asking questions through oral-based manner instead of ICT-based manner to the students.

In the core activities, the percentage of the ICT implementation might be consulted in Figure 2.

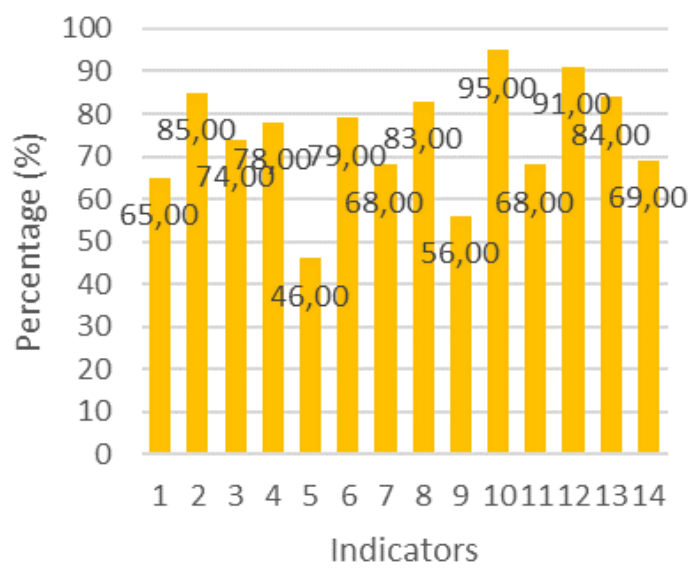

Figure 2. The Histogram of Compatibility for the ICT Implementation in the Core Activities

Legends of Indicators:

1 : Displaying problems

2 : Facilitating the opportunity for performing observation

3 : Facilitating the opportunity for raising questions

4 : Facilitating the provision of assignment

5 : Facilitating the opportunity for gathering information/performing trials

6 : Facilitating the opportunity for performing reasoning/associating

7 : Facilitating the opportunity for performing communication 


\section{Psychology, Evaluation, and Technology in Educational Research, 1 (1), 2018, 49}

Septiana Indri Hapsari, Kristian Handoyo Sugiyarto, Naoko Kosaka

8 : Facilitating the interactive learning process

9 : Facilitating the inspirational learning process

10 : Building the students' motivation

11 : Facilitating the students' active participation

12 : Facilitating the students' creativity

13 : Facilitating the students' independence

14 : Facilitating the students' attitude development

Departing from the results in Figure 2, it is apparent that the ICT implementation has been very good in the second indicator (facilitating the opportunity for performing observation), the fourth indicator (facilitating the provision of assignment), the sixth indicator (facilitating the opportunity for performing reasoning/associating), the eighth indicator (facilitating the interactive learning process), the tenth indicator (building the students' motivation), the twelfth indicator (facilitating the students' creativity), the thirteenth indicator (facilitating the students' independence), and the fourteenth indicator (facilitating the students' attitude development).

Such situation has taken place because the theme "Galaxy" in the learning process of Natural History involves the use of multiple pictures and videos. The use of ICT is able to bring the abstract concept of galaxy within the students' mind into the reality. As a result, the students' interest and curiosity are drawn and thus the students are encouraged to perform further observation and reasoning activities. This situation is in accordance to the results of a study by Yektyastuti \& Ikhsan (2016), which has found that the use of Android-based learning media brings about significant influence on the improvement of the students' academic achievement in terms of learning motivation and cognitive learning results. In addition, it has been found from the study as well that the ICT implementation is able to facilitate the students' creativity development and learning independence and also the teachers' provision of assignment and interactive-communicative learning process with the students. Yektyastuti \& Ikhsan (2016) further states in her study that the use of learning media has strong association to the reasoning stage because through learning media the abstract information might be turned into the concrete information while the complex information might be simplified. Thereby, the students will be motivated in attending the learning process, specifically the theme "Galaxy."

The ICT implementation is also good for the first indicator (displaying problems), the seventh indicator (facilitating the opportunity for performing communication) and the ninth indicator (facilitating the inspirational learning process) because the use of ICT for displaying problems as part of the students' apperception is easier and more interesting for the students. Consequently, the students will be more assisted in identifying the problems that they should discuss. Despite these results, the ICT implementation has not been sufficient for the fifth indicator (facilitating the opportunity for gathering information/performing trials) and the eighth indicator (facilitating the interactive learning process). Such situation occurs because the teachers have been accustomed to provide assignments to the students by means of oral manner or of written manner over the blackboard instead of having the assignments provided through the use of ICT. This situation should be improved in order that the use of ICT will not be dominant on one activity. In the closing activities, the percentage of the ICT implementation might be consulted in Figure 3.

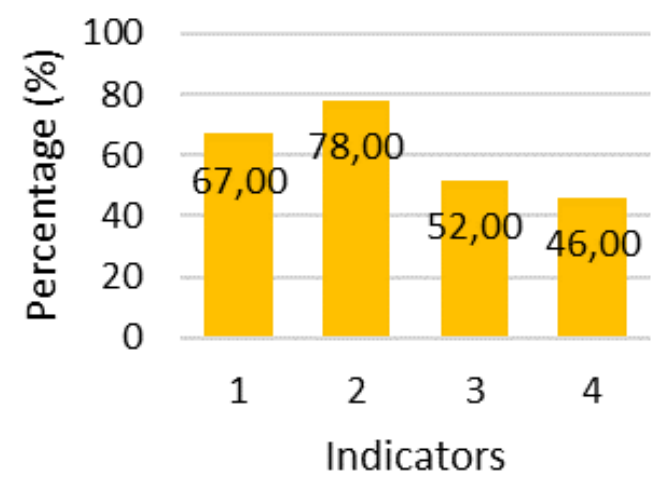

Figure 3. The Histogram of Compatibility for the ICT Implementation in the Closing Activities 
Psychology, Evaluation, and Technology in Educational Research, 1 (1), 2018, 50

Septiana Indri Hapsari, Kristian Handoyo Sugiyarto, Naoko Kosaka

Legend of Indicators:

1 : Facilitating the conclusion drawing/verification

2 : Facilitating the reflection

3 : Providing feedback on learning process and results

4 : Delivering further lesson plan

Departing from the results in Figure 3, it is apparent that the ICT implementation has been very good for the first indicator (facilitating the conclusion drawing/verification) and the second indicator (facilitating the reflection). In the same time, it is also apparent that ICT implementation has been good for the third indicator (providing feedback on learning process and results) and the fourth indicator (delivering further lesson plans). The reason is that the teachers have not been accustomed to deliver the future learning materials by using the ICT. Instead, the teachers deliver the future learning plans only by means of oral presentation. Similarly, they also rely on the use of oral presentation for eliciting feedback and drawing conclusions. Frequently, the teachers lead the students to draw the conclusions by means of oral question and answer session. In the assessment activities, the percentage of ICT implementation might be consulted in Figure 4.

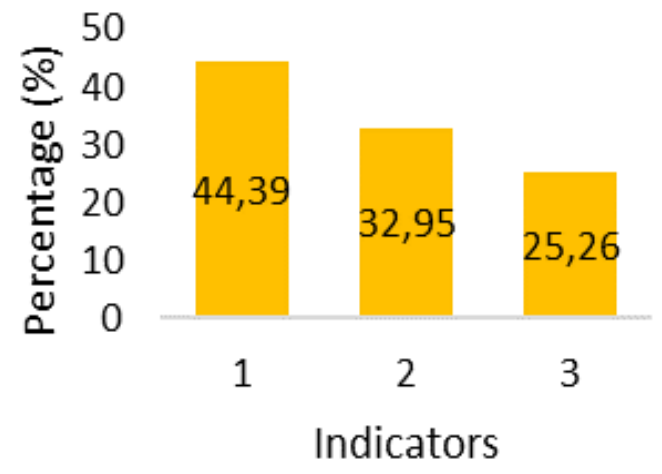

Figure 4. The Histogram of Compatibility for the ICT Implementation in the Assessment Activities

Legend of Indicators:

1 : Facilitating assessment

2 : Facilitating remedial

3 : Facilitating enrichment

Departing from the results in Figure 4, it is apparent that the ICT implementation has been poor for the first indicator (facilitating assessment) and the second indicator (facilitating remedial). Furthermore, it is also apparent that the ICT implementation has been very poor for the third indicator (facilitating enrichment). The reason is that the teachers rarely rely on the use of ICT for the assessment, the remedial and even the enrichment activities. Instead, the teachers frequently rely on the use of paper-based test as part of the assessment activities. Not to mention, the teachers rarely use the ICT for performing both the remedial activities and the enrichment activities. In fact, there are several the teachers who only perform the remedial activities.

In addition to viewing the percentage of ICT implementation compatibility on the facilitation of each learning indicators, the researcher will view the composites of ICT implementation on the overall introductory, core, closing and assessment activities. The accumulation of ICT implementation into the learning process of Natural History under the theme "Galaxy" throughout the City of Yogyakarta might be consulted in Figure 5.

Departing from the results in Figure 5, it is apparent that the data triangulation from the observers, the teachers and the students show similar assessment toward the ICT implementation. In this regard, the measurement from the observers, the teachers and the students have similar agreement. As a result, the decision that will be made in relation to the ICT implementation might be stronger. Then, the accumulation on the data triangulation from the observers, the teachers and the students might be consulted in Figure 6 . 
Psychology, Evaluation, and Technology in Educational Research, 1 (1), 2018, 51

Septiana Indri Hapsari, Kristian Handoyo Sugiyarto, Naoko Kosaka

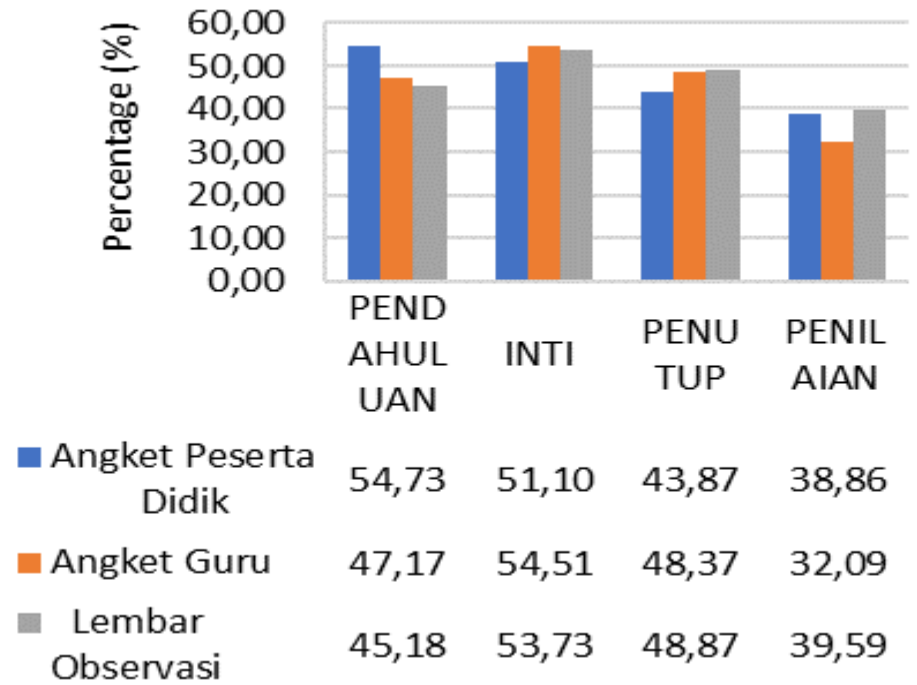

Figure 5. The Histogram of Compatibility for the ICT Implementation into the Learning Process of Natural History under the theme "Galaxy" throughout the Junior High Schools in Yogyakarta

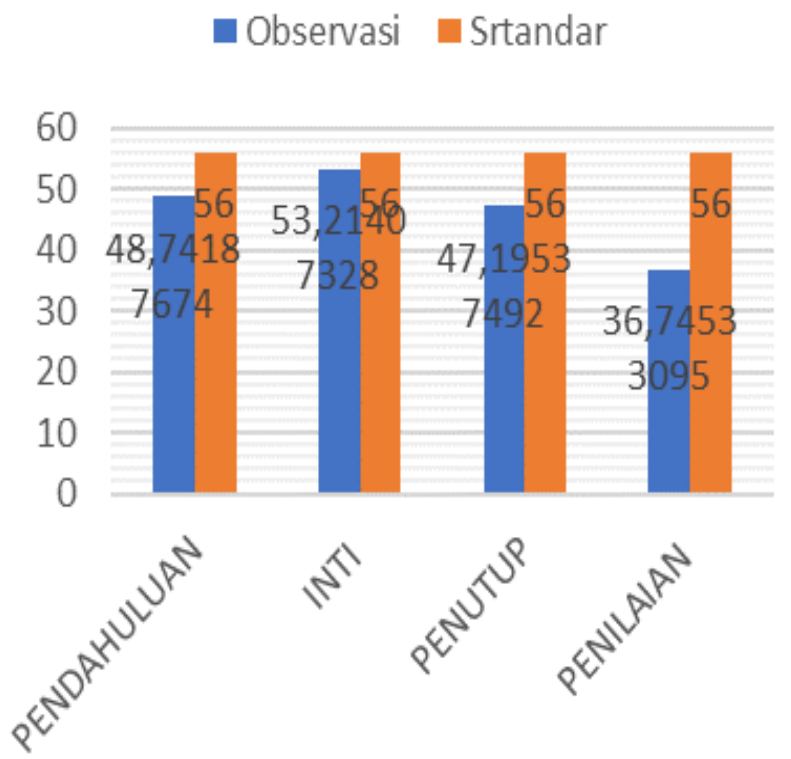

Figure 6. The Histogram of Compatibility for the ICT Implementation in the Observed Situations According to the Standard

The ICT implementation into the learning process of Natural History under the theme "Galaxy" for all activities is actually still below the standard. The ICT implementation into the introductory, the core and the closing activities fall into the "Good" category but the ICT implementation into the assessment activities fall into the "Poor" category. This situation might occur because the teachers" preparedness in implementing the ICT is still low and, not to mention, the number of Natural History teachers who are familiar with and able to implement numerous types of ICT is still low. Not to mention, the limited time and the overwhelming tasks that the teachers have cause the teachers to be unable to the prepare the learning materials by using ICT properly. As a result, the students are asked to design the learning materials of the theme "Galaxy" for their presentation. Although the learning process has been performed by means of presentation, there are still the teachers who have not realized or who have even neglected the importance of pedagogy in the learning activities. Some of the teachers have not even been able to pursue the balance between the ICT use and their pedagogy. This statement is confirmed by the observation results: some teachers hold a conversation with the other students during a presentation and yet the content of their conversation are not totally related to the 
learning materials. On the other hand, some of the teachers have not been able to manage their classrooms and thus their students become indifferent and do not pay attention to the learning activities. Furthermore, there are also some other teachers who leave their classrooms and ask the students to do the presentation independently. Therefore, it is no wonder that the ICT implementation has fallen into the "Poor" category since the implementation is not appropriate and effective.

There are many types of ICT that might be implemented into the learning process of Natural History throughout the junior high schools in the City of Yogyakarta. The types of ICT that have been used then might be consulted in Table 3.

Table 3. The Type of ICT that Have Been Frequently used in the Learning Process of Natural History under the theme "Galaxy"

\begin{tabular}{ccr}
\hline Category of Activities & Media & Percentage (\%) \\
\hline & Edmodo & 20.00 \\
Introductory & Video & 20.00 \\
& Figure & 20.00 \\
& PPT & 100.00 \\
\hline & PPT & 100.00 \\
& Text & 20.00 \\
& Figure & 20.00 \\
Core & Video & 20.00 \\
& Edmodo & 20.00 \\
& Email & 20.00 \\
\hline \multirow{2}{*}{ Closing } & Edmodo & 20.00 \\
& PPT & 100.00 \\
\hline Assessment & Edmodo & 20.00 \\
\hline
\end{tabular}

Departing from the results in Table 3, it is apparent that PowerPoint is the ICT Type that has been frequently used in the learning process. Such results are logical because both the teachers and the students have the capacity to design a presentation by means of PowerPoint.

As having been explained, the third stage, namely Outcomes, is the stage of identify the students' achievement after the implementation of ICT into the learning process of Natural History and also the obstacles that both the teachers and the students had encountered during the implementation of ICT into the learning process of Natural History under the "Galaxy" theme. Therefore, the results of data analysis on the Outcomes stage consist of the assessment results from the students' achievement and the obstacles that have been encountered during the ICT implementation into the learning process of Natural History under the theme "Galaxy." In the assessment, the students' achievement is compared to the passing grade. Then, based on the results of daily test for the theme "Galaxy" it is found that the students' achievement is only $37.10 \%$. These results are still far under the expectation namely $70.00 \%$. Thereby, it might be concluded that the ICT implementation in the learning process of Natural History has not been maximum and effective for the students. There are many factors that lead to the situation and one of the factors is related to the teachers' preparedness in implementing ICT into the learning process and the teachers' pedagogy during the conduct of teaching process by using the ICT. As a result, the students' achievement has not been maximum as well. In other words, although the ICT has been well implemented the conduct of teaching-learning process still demands good pedagogy. In order to follow up the ICT implementation in the future, there should be revisions toward the ICT implementation in order to meet the minimum standard criteria on the compatibility of ICT implementation into the learning process of Natural History under the theme "Galaxy." In the meantime, the obstacles that both the teachers and the students have encountered within the ICT implementation are the LCD that has not been directly connected to the laptop and the ill-performing Internet connection that has been found in both the schools and the students' house.

\section{CONCLUSIONS}

Departing from the discussions above, it might be concluded that the teachers' preparation to implement ICT into the learning process of 2013 Curriculum Natural History under the theme "Galaxy" throughout the Junior High Schools in the City of Yogyakarta has not been maximum. The conclusion is indicated by the ICT implementation into the learning process of Natural History under 
the theme "Galaxy" throughout the Junior High Schools in the City of Yogyakarta still falls into the "Moderate" category with $46.47 \%$. In specific, the ICT implementation has achieved $48.74 \%$ in the introductory activities, $53.21 \%$ in the core activities, $47.20 \%$ in the closing activities and $36.74 \%$ in the assessment activities. ICT is most dominantly implemented in the core activities because the teachers have not tried to implement the ICT in maximum capacity into the other category of activities. The statement shows that the ICT implementation still only serves as a medium of information delivery.

Although the ICT has been implemented into the learning process of Natural History under the theme "Galaxy," the students' achievement is not satisfying yet. The statement is confirmed by the fact that there are only $37.10 \%$ students who achieve the passing grade. The possibility is that the students' have not been accustomed to using the ICT and thus the learning process becomes ineffective so that the students' understanding is still low. In addition to having unsatisfying results, within the process of ICT implementation several obstacles have still been found such as the LCD that has not been directly connected to the laptop and the Internet connection over Wi-Fi facility that has not been stable both in the schools and the students' house.

\section{REFERENCES}

Ali, G., Haolader, F.A., \& Muhammad K. (2013). The role of ICT to make teaching-learning effective in higher institutions of learning in Guanda. International Journal of Innovative Research in Science, Engineering and Technology (An ISO 3297: 2007 Certified Organization). Vol. 2, Issue 8, August 2013.

Carin, A.A \& Sund, R.B (1989). Teaching science through discovery. New York, NY: Merril Publishing Company.

Chiappetta, E. L., \& Koballa, T. R. (2010). science instruction in the middle and secondary schools developing fundamental knowledge and skills. New York, NY: Pearson.

Gliem, J. A., \& Gliem, R. R. (2003). Calculating, interpreting, and reporting Cronbach's alpha reliability coefficient for Likert-type scales. Midwest Research-to-Practice Conference in Adult, Continuing, and Community Education.

Kementerian Pendidikan dan Kebudayaan Republik Indonesia. (2013). Peraturan Menteri Pendidikan Dan Kebudayaan RI Nomor 68, Tahun 2013, Tentang Kerangka Dasar Dan Struktur Kurikulum Sekolah Menengah Pertama/Madrasah Tsanawiyah.

Mardapi, D. (2008). Teknik penyusunan instrumen tes dan non-tes. Yogyakarta: Mitra Cendikia Press.

Pacific Policy Research Center (2010). $21^{s t}$ century skils for students and teachers. honolulu. Kamehameha Schools Research \& Evaluation Division.

Rusman, D. K., \& Riyana, C. (2011). Pembelajaran berbasis teknologi informasi dan komunikasi. Jakarta: Rajawali Pers.

Sarjono, H \& Julianita, W. (2011). SPSS vs LISREL sebuah pengantar, aplikasi untuk riset. Jakarta: Salemba Empat.

Subali, B \& Suyata, P.(2012). Pengembangan item tes konvergen dan divergen dan penyelidikan validitasnya secara empiris. Yogyakarta: DANDRA

Surjono, H.D. (2012). Implementasi ICT dalam pembelajaran IPA. Yogyakarta. Seminar Nasional Pendidikan IPA IV di UNY tanggal 6 Oktober 2012.

Sutrisno. (2011). Pengantar pembelajaran inovatif berbasis teknologi informasi \& komunikasi. Jakarta: Gaung Persada Press.

Tantriadi, Y. (2013). Pembuatan ensiklopedia interaktif tata surya untuk anak SMP. CALYPTRA, 2(1), 1 - 7. Retrieved from http://journal.ubaya.ac.id/index.php/jimus/article/view/409.

Toomey, R. (2001). Information and communication technology for teaching and learning. Department of Education, Training and Youth Affairs.

Trefil, J \& Hazen, R.M. (2010). Sciences an integrated approach. New York, YK: John Wiley \& Sons, Inc. 
Psychology, Evaluation, and Technology in Educational Research, 1 (1), 2018, 54

Septiana Indri Hapsari, Kristian Handoyo Sugiyarto, Naoko Kosaka

Viera, A. J., \& Garrett, J. M. (2005). Understanding interobserver agreement: the kappa statistic. Fam med, 37(5), 360-363.

Voogt, J.(2009). How different are ICT-supported pedagogical practices from extensive and nonextensive ICT-using science teachers. Educ Inf Technol.DOI 10.1007/s10639-009-9092-1.

Wonorahardjo, S. (2009). Dasar-dasar Sains menciptakan masyarakat sadar Sains. Malang: PT Indeks.

Yektyastuti, R., \& Ikhsan, J. (2016). Pengembangan media pembelajaran berbasis android pada materi kelarutan untuk meningkatkan performa akademik siswa SMA. Jurnal Inovasi Pendidikan IPA, 2(1), 88-99. doi:https://doi.org/10.21831/jipi.v2i1.10289 